Article

\title{
The State of the Art of Use of the Concept of Ecosystem Services within Spatial Plans in the Czech Republic
}

\author{
Jiří Schneider ${ }^{1, *}$ and Hana Kubíčková ${ }^{2}$ \\ 1 Department of Environmentalistics and Natural Resources, Faculty of Regional Development and \\ International Studies, Mendel University, 61300 Brno, Czech Republic \\ 2 Department of Landscape Management, Faculty of Forestry and Wood Technology, Mendel University, \\ 61300 Brno, Czech Republic; hanicta@centrum.cz \\ * Correspondence: jiri.schneider@mendelu.cz
}

Received: 29 September 2020; Accepted: 27 October 2020; Published: 29 October 2020

check for updates

\begin{abstract}
Although the use and management of ecosystem services (ES) resources and the promotion of their provision are a standard and necessary part of spatial planning tools and documents, a direct implementation of this concept is exceptional. Researchers and entire projects have so far focused mainly on identification of ecosystem services and their resources in urban environment, or on the analysis of their occurrence in spatial planning documents. That was the goal of our research as well. Spatial planning documents, systematically and methodically re-defined using ecosystem services, are what is still lacking. Our article presents the results of the analysis of the use of ecosystem services in spatial plans of five cities, regional centers in the Czech Republic. We used a text evaluation methodology focused on the explicit and implicit expression of ecosystem services. We analyzed the overall approach to the creation of spatial plans. In addition to the spatial plans, we also analyzed their assignments (SPA). We found that the current spatial planning methodology does not work with the ecosystem services approach (ESA) systemically. It focuses mainly on ES resources and implicitly envisages their provision. SPAs are a more flexible and effective tool for enforcing ESA in spatial planning than the lengthy legislative process. However, this presupposes greater knowledge of SPA among the public and decision makers.
\end{abstract}

Keywords: ecosystem services; spatial planning; urban planning; regional planning; decision support system; sustainable landscape management

\section{Introduction}

\subsection{State of the Art of Integration of Ecosystem Services into Spatial Planning}

The actual framework of ecosystem services (ES) has not yet been systematically integrated directly into spatial planning [1]. Although ecosystem services are a powerful spatial and environmental planning tool that can help decision-makers to better understand the changes between different development scenarios for natural ecosystems [2], they can also bring a new facilitating approach in a comprehensive and long-term solution to the sustainable development of urban areas [3-6]. The direct integration of the concept of ecosystem services and their categories into spatial planning documents could facilitate the way for the inclusion of information on both the environment and public values in the implementation of the process of sustainable territorial development [7].

The design of the spatial plan defines the distribution and determines the availability of individual territorial functions within the city, thus influencing the offer of ecosystem services for the inhabitants of the territory $[6,8,9]$. Therefore, the inclusion of ecosystem services in land use plans is considered an 
indicator of their quality [2]. Authors such as [10] have addressed this issue in the last decade; [2,11-15] by solving the process of integration of ecosystem services into spatial planning. At this time, studies were also conducted to examine whether ecosystem services were actually included in spatial planning documents and by what process they were integrated in individual documents [1,2,10,16-21]. For example, studies addressing ecosystem services and incorporating them into spatial planning documents have shown that while only a few documents explicitly referred to ecosystem services, many documents also found indirect references to the benefits of ecosystems of natural green areas contained in the spatial planning document [1,16-21]. However, the distance between objectives and outcomes can be attributed to differences in countries' spatial planning approaches, which should also be placed into the wider economic, institutional, and legislative context [22]. With gradual impacts of global climate change, the so-called multi-hazard risks assessment $[23,24]$ is also gaining in importance in terms of planning and implementing measures. Although this article focuses mainly on ecosystem services, ecosystem disservices are an equally important phenomenon for spatial planning.

However, the integration of the ES concept in policy making and planning is not mainstream $[25,26]$. A key tool for policymakers has also become the mapping of ecosystems and their services, because it allows us to apply econometric methods in order to support a monetary valuation of biodiversity [27]. According to Albert et al., there are three key research themes: (i) requirements and interests of planners and decision-makers for integrating ES in different application contexts, (ii) approaches to applying ES in (participatory) planning, and (iii) potential impacts of integrating ES in policy and decision-making [28]. Particular barriers for integration of the ES concept as a heuristic tool for urban planning and policy-making are to be expected considering the need for (1) a change of planning paradigms and routines towards more systemic and holistic thinking, e.g., by linking ecological, social, and economic considerations; and (2) a shift towards more interdisciplinary thinking and coordination, given that different fields in administration are usually in separate departments [29].

Support for research and development of ecosystems in urban blue-green services is also happening through international projects. The aim of the OpenNess project (Operationalization of Natural Capital and Ecosystem Services) is to transfer the concept of ecosystem services and natural resources into a functional framework that will enable practical solutions for integrating ecosystem services into spatial planning and decision-making processes and others [30]. Mapping and assessing ecosystems and their services (MAES) is at the heart of the EU's biodiversity strategy. The ESMERALDA project (Enhancing ecoSysteMsERvicesmAping for poLicy and Decision mAking) seeks to bring a flexible methodology that will provide basic building blocks for pan-European and regional evaluation [31,32]. Another supporting tool, BISE (the Biodiversity Information System for Europe) provides data and information on biodiversity to support the implementation of the EU biodiversity strategy. And finally, CICES (the Common International Classification of Ecosystem Services) is a widely used system for evaluating ecosystem services.

Research questions are formulated as follows:

(1) How is the ES concept, in explicit and implicit terms, represented in spatial plans?

(2) To what extent and which ES are referred to within spatial plans and their chapters?

(3) How are measures of spatial plans targeted at ecosystem services?

(4) What are the possibilities for innovation of spatial plans through ecosystem services?

\subsection{Spatial Planning in the Czech Republic}

Spatial planning in the Czech Republic is governed by Act No. 183/2006 Coll., On Spatial Planning and Building Regulations (Building Act), Decree No. 500/2006 Coll., On Spatial Analytical Documents, Spatial Planning Documentation and the Method of Spatial Planning Records activities, and Decree No. 501/2006 Coll., on general requirements for land use.

The aim of spatial planning in the Czech Republic is to create preconditions for the construction and sustainable development of the territory, consisting in a balanced relationship of conditions for a 
favorable environment, economic development, and cohesion of the community, and which satisfies the needs of the current generation without compromising the living conditions of future generations [33].

The task of spatial planning is, among other things, (a) to determine and assess the state of the territory and its natural, cultural, and civilizational values; (b) to examine and assess the need for changes in the territory, public interest in their implementation, and their benefits, problems, and risks with regard to, for example, public health, the environment, and its economic use; (c) to create conditions in the area for reducing the risk of ecological and natural disasters and eliminating their consequences, especially close to nature; and (d) to regulate the extent of areas for the use of natural resources, and so on [33].

Planning tools (according to the Building Act) are instruments to enforce planning objectives and tasks in the territory at the national, regional, and local levels. They include Planning Analytical Materials, Planning Studies, Spatial Development Principles, Spatial Plans, Regulatory Plans, Spatial Development Policy, and Planning Permission. An overview of individual spatial planning tools and their main links to the spatial plan and its content is presented in Figure 1.

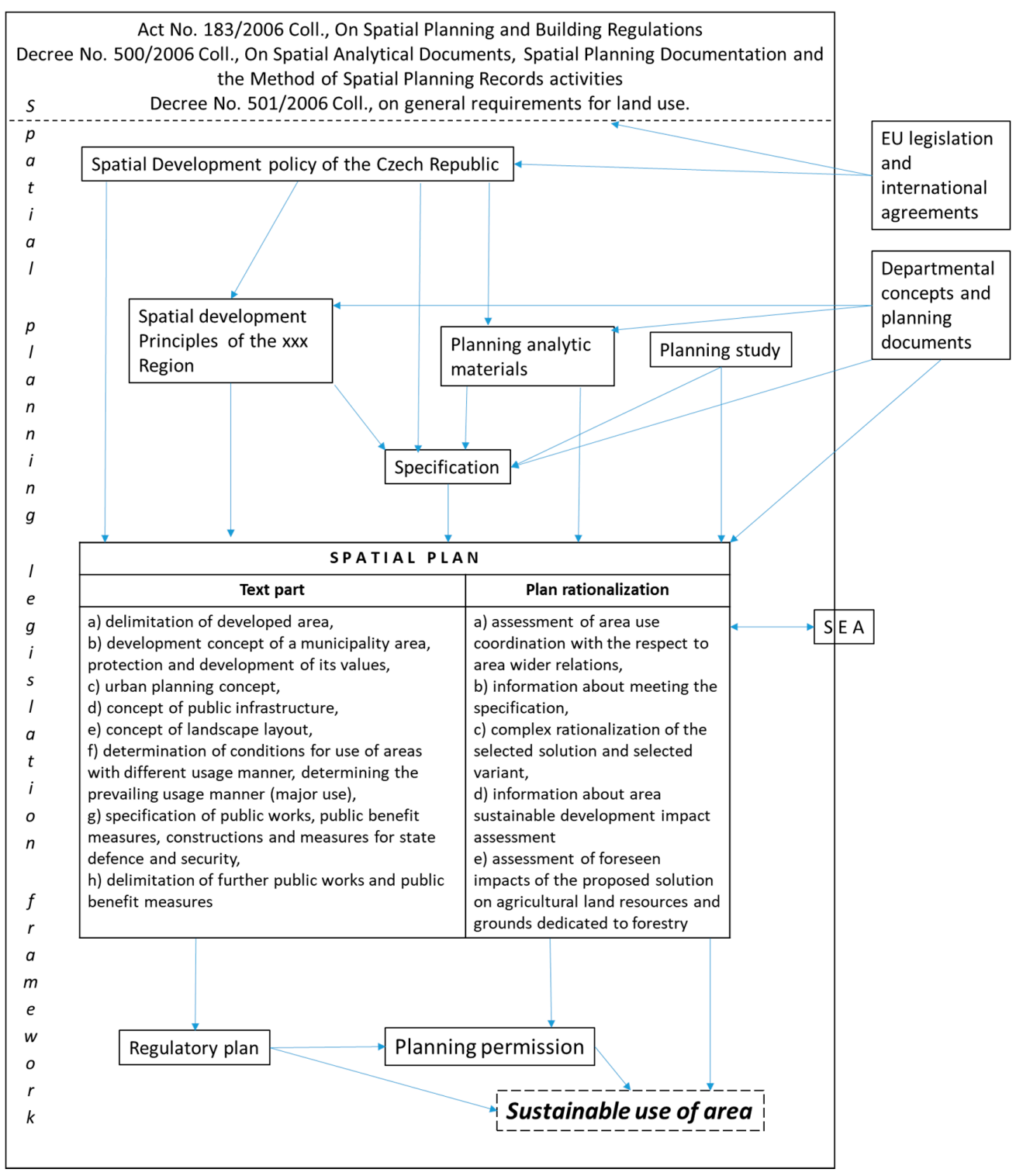

Figure 1. An overview of individual spatial planning tools and their main links to the spatial plan and its content. 


\section{Materials and Methods}

\subsection{Description of the Area of Interest}

Five of the thirteen regional centers in the Czech Republic (except the capital city of Prague) were selected for the analysis of spatial plans. Olomouc and Plzeň have approved spatial plans in recent years (see Table 1 for details and Figure 2 for location). Brno, Hradec Králové, and Liberec have the drafts of their spatial plans in the process of public discussion. In all cases, therefore, these are new documents that should reflect the current problems and needs of the cities and their inhabitants: floods since 1997, drought in recent years, increased awareness of climate change, the overall improvement of environmental literacy, as well as persistent pressures from developers to take land or the reluctance of large farmers to choose environmentally friendly practices. These are the reasons why civil society pays increased attention to the spatial planning process, the development of blue-green infrastructure, and nature-based solutions.

Table 1. Overview of the cities and documents used for the analysis of ecosystem services in spatial plans.

\begin{tabular}{|c|c|c|c|c|c|}
\hline City & Region & $\begin{array}{l}\text { Population on } \\
1 / 1 / 2020 *\end{array}$ & Document Type & Year & Notice \\
\hline \multirow{2}{*}{ Brno } & \multirow{2}{*}{$\begin{array}{l}\text { Southern } \\
\text { Moravia }\end{array}$} & \multirow{2}{*}{381,346} & $\begin{array}{c}\text { The full text of the } \\
\text { spatial plan } \\
\text { assignment }\end{array}$ & 2007 & 80 pages \\
\hline & & & Spatial plan proposal & 2020 & $\begin{array}{l}\text { Discussion of the proposal. } \\
\text { Incorporation of public } \\
\text { comments. Range approx. } \\
700 \text { pages ( } 1 \text { round) }\end{array}$ \\
\hline Hradec Králové & Králové-hradecký & 92,939 & Spatial plan proposal & 2016 & $\begin{array}{l}\text { Discussion of the proposal. } \\
\text { Incorporation of public } \\
\text { comments. Range approx. } \\
1600 \text { pages }\end{array}$ \\
\hline \multirow[b]{2}{*}{ Liberec } & \multirow[b]{2}{*}{ Liberecký } & \multirow[b]{2}{*}{104,802} & $\begin{array}{l}\text { The full text of the } \\
\text { spatial plan } \\
\text { assignment }\end{array}$ & 2008 & 41 pages \\
\hline & & & Spatial plan proposal & 2018 & $\begin{array}{l}\text { Discussion of the proposal. } \\
\text { Incorporation of public } \\
\text { comments. Range approx. } \\
1270 \text { pages }\end{array}$ \\
\hline Olomouc & Olomoucký & 100,663 & Spatial plan & 2019 & \\
\hline Plzeň & Plzeňský & 174,842 & Spatial plan & 2016 & \\
\hline
\end{tabular}

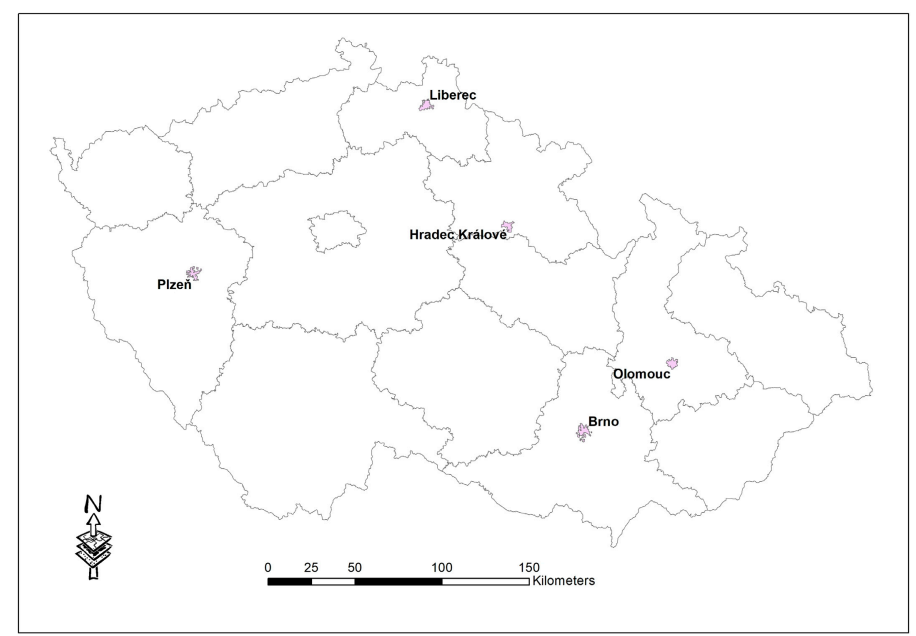

Figure 2. Location of model cities in the Czech Republic. 
Spatial plans or their designs should also be developed using modern approaches to creating and solving problems. The publicly accessible full texts of the Brno and Liberec spatial plans assignment was also used for the analysis.

\subsection{Methodological Steps}

An analysis of similar published procedures applied in other states and cities [18,29,34-36] was the first step. Attention was paid mainly to indicators and ways in which researchers analyzed the use of ecosystem services in spatial plans (see Table 2). The consensus was on ecosystem services according to TEEB (The Economics of Ecosystems and Biodiversity).

Table 2. The resulting categories of ecosystem services that were used for the evaluation of spatial planning documents [18,37-39], modified.

\begin{tabular}{ccc}
\hline Provisioning ES & Regulating and Supporting ES & Cultural ES \\
\hline Food supplies (biomass) & $\begin{array}{c}\text { Water quality regulation } \\
\text { Water management, runoff, and flood protection } \\
\text { Temperature regulation } \\
\text { Noise regulation }\end{array}$ & Recreation and tourism \\
\hline $\begin{array}{c}\text { Biomass } \\
\text { (wood and natural fibres) }\end{array}$ & $\begin{array}{c}\text { Air quality regulation } \\
\text { Support of formation and natural composition of soils } \\
\text { Mitigation of environmental extremes-regulation of } \\
\text { erosion and other natural hazards }\end{array}$ & $\begin{array}{c}\text { Landscape character and } \\
\text { aesthetic values }\end{array}$ \\
\hline Water (potable and service) & $\begin{array}{c}\text { Waste management } \\
\text { Regulation of pests and diseases }\end{array}$ & $\begin{array}{c}\text { Natural and cultural } \\
\text { heritage-intellectual and } \\
\text { scientific values }\end{array}$ \\
\hline & $\begin{array}{c}\text { Support of life cycles and processes, pollination } \\
\text { Support for species and ecosystem } \\
\text { biodiversity/wildlife/plants }\end{array}$ & \\
\hline
\end{tabular}

The main methodological approach used is the analysis of the textual content of spatial plans (or their proposals) of five regional centers in the Czech Republic-Brno, Hradec Králové, Plzeň, Olomouc, and Liberec. In order for the results to be comparable with previous work, the following methodological steps were then chosen to answer the research questions:

(1) How is the ecosystem services approach (ESA), in explicit and implicit terms, represented in spatial plans?

The text was analyzed in terms of the methodological use of ESA, or the use of the terms ecosystem services, ecosystem functions, and their alternatives in spatial plans.

(2) To what extent and which ES are referred within spatial plans and their chapters?

For the analysis, we selected the most frequently used ecosystem services according to TEEB in previous research. In case the use of these terms was not found, we linked the terminology used to this scale.

(3) How are measures of spatial plans targeted at ecosystem services?

To answer the question, we analyzed whether the support of ecosystem services is specifically the goal or the key reason for the individual measures, or, if not, what other arguments are used for this support.

(4) What are the possibilities for innovation of spatial plans through ecosystem services?

Based on the results of the previous three points, we identified possible mechanisms for ecosystem services to innovate the existing approach to their processing.

Categories of ecosystem services were identified in two steps in the relevant chapters of the spatial planning documents. First, Table 2 shows the content classification of categories of ecosystem services according to the classification protocol according to Cortinovis and Genelettti, 2018, Geneletti et al., 2020, Geneletti and Zardo, 2016, and Mederly, Černecký et al., 2020. 
The second step is value expression of the degree of content integration of ecosystem services in spatial plans according to Geneletti and Zardo [38], see Table 3.

Table 3. Value expression of the degree of content integration of ecosystem services in selected spatial planning documents according to Geneletti and Zardo [38] (modified).

\begin{tabular}{cl}
\hline Value & \multicolumn{1}{c}{ The Rate of Incorporation of the Content Categories of Ecosystem Services } \\
\hline 0 & The spatial planning document does not contain any concept of ES or ES-related objectives. \\
\hline 1 & $\begin{array}{l}\text { The link between ecosystems and the ES concept can be found in the spatial planning } \\
\text { document. The document mentions the functions and processes on which the provision of the } \\
\text { ES depends. This defines ecosystem protection objectives, but does not refer directly to the ES. }\end{array}$ \\
\hline & $\begin{array}{l}\text { The spatial planning document mentions the functions and processes on which ES delivery } \\
\text { depends and identifies the elements that define the potential of the ES. It formulates ecosystem } \\
\text { protection objectives that are directly related to ES provision. However, they are completely } \\
\text { descriptive and lack specific applications and analysis. }\end{array}$ \\
& $\begin{array}{l}\text { The spatial planning document carries out a basic qualitative assessment of the current state of } \\
\text { the ES through the analysis and application of the ES concept. The lack of a detailed analysis } \\
\text { and clear identification of beneficiaries and demand for the ES shows only a limited level of } \\
\text { application of the ES concept at a specific level of spatial planning decision-making. }\end{array}$ \\
& $\begin{array}{l}\text { The spatial planning document defines quantitative objectives related to the provision of the } \\
\text { ES through the analysis and application of the ES concept. It defines the depth of the } \\
\text { application of the ES concept in the analyses of ES provision, including quantitative } \\
\text { measurement, detailed assessment, and identification of ES demand and beneficiaries. }\end{array}$ \\
\hline
\end{tabular}

\section{Results}

Spatial planning tools (including spatial plans) in the Czech Republic have a structure fixed by legislation. This also affects the unified approach to the methods of elaboration of spatial plans, the character of which is therefore similar. This is a partial problem for the quality and creativity when creating spatial plans. Even with different requirements, given the specific conditions of individual cities, we will not find a progressive approach to processing documentation or solving problems. The findings can therefore be taken in a generalized way for the whole set of spatial plans and their proposals. The presented conclusions will apply to each of them.

\subsection{How is the ES Concept, in Explicit and Implicit Terms, Represented in Spatial Plans?}

We did not find an explicit expression of ecosystem services, or of the whole approach in the spatial plans of Czech cities. The terms "social functions", "landscape functions", "functions of green infrastructure", or "non-production functions" are only rarely used. Non-productive functions are mainly associated with forest stands. This connection is given by the Forest Act, which uses the term "land intended for forest functions". In addition, from the research point of view, this topic has the longest tradition in the Czech Republic and is the most developed. Implicitly, it is talked about in partial effects such as flood protection, recreation, or nature protection (see below). Overall, however, the link between spatial plans and ecosystem services is very weak.

\subsection{To What Extent and Which ES Are Referred to within Spatial Plans and Their Chapters?}

\subsubsection{The Spatial Plan Assignment}

The content of the Spatial Plan Assignment is the formulation of general and more specific requirements for each sub-chapter of the Spatial Plan. It is based on the current state of natural components and the current needs for the development of the city. They can be formulated clearly and comprehensibly, e.g., in the requirement, "ss part of the solution of the functional use of agricultural land, create favorable conditions for the development of livestock breeding for non-productive purposes, 
i.e., for recreation and leisure". This requirement focuses on the production of ecosystem services, incorporates their philosophy, and does not need to be formulated within the ESA.

The main objectives of the assignment include keywords such as sustainable, environment, quality of life, reduction of environmental burdens, and protection and restoration of natural and landscape values, including watercourses-revitalization recreational potential. In addition to these, it also includes sustainable mobility, flexibility, and development areas as key points. It is therefore clear that the assignment aims to address environmental issues.

From the Assignments of the Brno and Liberec spatial plans, it is clear that spatial planning is focused primarily on the sources of ecosystem services (land use), and sometimes on the source of some prioritized ES (e.g., recreational greenery). Ecosystem services as a target for measurement (regardless of source) are not formulated anywhere. However, the assignment contains requirements for ensuring the use of ecosystem services, such as the permeability of the landscape for holidaymakers or the intention to declare a nature park or NATURA 2000 sites.

The functions of forests are mentioned only in general terms. They need to be protected and the recreational infrastructure needs to be addressed as much as possible. On the other hand, individual functions or ecosystem services of forests belong to forestry plans such as the Forest Management Plan or Regional plan of forests development in terms of planning.

When dealing with noise pollution, there are no requirements for noise reduction through ecosystem services, but rather the organization of transport and noise sources.

Air pollution is again primarily a solution (elimination of impacts) of sources of pollution. However, there is a requirement for "the highest possible share of green space in all development areas as a factor of a significant factor eliminating dust and improving air quality".

Recreation and greenery is a separate chapter. It is divided into several articles. However, even here we will not find a more detailed use of ecosystem services:

- Greenery as a part of all functional areas-the emphasis is mainly on green horizons and additional (unspecified) functions.

- Urban greenery - the issue is conceived only as the design of new areas of parks, without functional concretization. However, this does not mean that the comments cannot be used in the actual design of the plan.

- Suburban landscape-the concurrence of recreation and nature protection is respected here, no other ESs are listed.

- Recreation areas-recreational potential and use is given more in general.

- Allotment localities—existing ones in the assignment are perceived mostly negatively (they make the city impassable, individual recreation at the expense of the general one). On the other hand, they are accepted as a traditional form of leisure (the big boom in the 70s and 80s of the 20th century). The aim is the localization reorganization of allotment colonies-to propose a new use of areas with existing ones and to find a place for new allotment colonies.

The protection of ecosystem services resources is also required as a measure in the Geology subchapter-all risk or limiting factors resulting from geological and hydrogeological environmental conditions must be taken into account, and risks must be minimized in areas of threat to groundwater quality.

From the above analysis of the assignment, it is clear that the contracting authorities are not able to define ecosystem services and therefore not able to target them more precisely with their measures. Nevertheless, the production or provision of ecosystem services (not directly, but through their nominal expression) is generally ensured through awareness of the importance and protection of their resources.

Table 4 presents other individual mentions of target ecosystem services, as can be found in the Spatial Plan Assignment. 
Table 4. An overview of mentions of ecosystem services within Spatial Plan Assignments of the cities of Brno and Liberec.

\begin{tabular}{|c|c|}
\hline Chapter of Assignment & $\begin{array}{l}\text { Targeting Ecosystem Services (Explicitly, Implicitly, } \\
\text { Generally Mentioned), Their Usage, Sources, or Trade-Offs }\end{array}$ \\
\hline Planning analytic materials requirements & Air quality; pleasant living conditions \\
\hline Development concept of a municipality area & $\begin{array}{l}\text { Water retention; reduction of harmful effects; minimization of } \\
\text { environmental risks; roles of mountain ecosystems * }\end{array}$ \\
\hline Urban planning concept & Elimination of heat island; microclimate \\
\hline $\begin{array}{l}\text { Housing areas, natural areas, forests, water } \\
\text { and water management areas }\end{array}$ & $\begin{array}{l}\text { Individual areas are implicitly assumed to be a source of } \\
\text { ecosystem services }\end{array}$ \\
\hline Recreation areas & Conflicts with nature conservation * \\
\hline $\begin{array}{l}\text { Requirements for the protection and } \\
\text { development of territory values }\end{array}$ & $\begin{array}{l}\text { Nature conservation; drinking and mineral water; natural } \\
\text { resources in general, incl. landscape values }\end{array}$ \\
\hline Civilization values & $\begin{array}{l}\text { Drinking and mineral water; flood protection (solved by } \\
\text { technical measurements); recreation }\end{array}$ \\
\hline Other requirements & $\begin{array}{l}\text { Soil protection; air quality; water quality; geology; nature and } \\
\text { landscape-in general, without specification }\end{array}$ \\
\hline
\end{tabular}

* Assignment of Spatial plan Liberec.

\subsubsection{Text Part of Spatial Plan}

The chapters of the text parts of the spatial plans, which should inherently address or at least touch on ecosystem services, are as follows:

- Development concept of a municipality area, protection and development of its values

- Urban planning concept

- Concept of public infrastructure

- Concept of landscape layout

- Determination of conditions for use of areas with different usage manner, determining the prevailing usage manner (major use)

- Specification of public works, public benefit measures

The text part of the spatial plans approaches the formulation of target services similarly to the assignment of spatial plans-i.e., it focuses primarily on the resources of ecosystem services and their protection. This is often implemented through technical measures (e.g., influencing runoff conditions as part of flood protection. In the case of water or forest areas, departmental/component legislative documents and plans express support for their ecosystem services (regional plans of forests development, plans of basin areas). Therefore, they are not specified in the spatial plans.

The ecosystem services of urban blue-green infrastructure (especially parks) are approached also implicitly.

Table 5 presents an overview of the use of ecosystem services in individual chapters of the text part of spatial plans of the cities of Brno, Hradec Králové, Olomouc, Plzeň, and Liberec. 
Table 5. Attention paid to ecosystem services in the assignment and individual chapters of spatial plans or proposals of urban spatial plans of the cities of Brno, Hradec Králové, Olomouc, Plzeň, and Liberec.

\begin{tabular}{|c|c|c|c|c|c|c|c|c|}
\hline Ecosystem Services According to TEEB & A & DCM & UPC & CPI & CLL & CADUM & SPW & $\mathbf{V}$ \\
\hline \multicolumn{9}{|c|}{ Provisioning ES } \\
\hline Food supplies (biomass) & $x$ & & & & $x$ & & & 1 \\
\hline Biomass (wood and natural fibres) & $\mathrm{x}$ & & & & $x$ & & & 1 \\
\hline Water (potable and service) & & & & $\mathrm{x}$ & $\mathrm{x}$ & $\mathrm{x}$ & & 1 \\
\hline \multicolumn{9}{|c|}{ Regulating and Supporting ES } \\
\hline Water quality regulation & & & & & & & & 0 \\
\hline Water management, runoff, and flood protection & $\mathrm{x}$ & $\mathrm{x}$ & $\mathrm{x}$ & $x$ & $\mathrm{x}$ & $x$ & $\mathrm{x}$ & 2 \\
\hline Temperature regulation & $\mathrm{x}$ & & & & $\mathrm{x}$ & & & 1 \\
\hline Noise regulation & $x$ & $\mathrm{x}$ & & $x$ & & $x$ & & 1 \\
\hline Air quality regulation & & & & & $\mathrm{x}$ & $\mathrm{x}$ & & 1 \\
\hline Climate regulation / Carbon sequestration & $\mathrm{x}$ & & & & $\mathrm{x}$ & & & 1 \\
\hline Support of formation and natural composition of soils & & & & & $\mathrm{x}$ & & & 1 \\
\hline $\begin{array}{l}\text { Mitigation of environmental extremes-regulation of } \\
\text { erosion and other natural hazards }\end{array}$ & $\mathrm{x}$ & & $\mathrm{x}$ & & $x$ & $\mathrm{x}$ & & 1 \\
\hline Waste management & $\mathrm{x}$ & & & $\mathrm{x}$ & & $\mathrm{x}$ & & 1 \\
\hline Regulation of pests and diseases & & & & & & & & 0 \\
\hline Support of life cycles and processes, pollination & & $x$ & & & & & & 0 \\
\hline $\begin{array}{l}\text { Support for species and ecosystem } \\
\text { biodiversity/wildlife/plants }\end{array}$ & & $x$ & & & $\mathrm{x}$ & $\mathrm{x}$ & & 1 \\
\hline \multicolumn{9}{|c|}{ Cultural ES } \\
\hline Recreation and tourism & $x$ & $\mathrm{x}$ & $x$ & $x$ & $x$ & $x$ & $x$ & 2 \\
\hline Landscape character and aesthetics values & $\mathrm{x}$ & $\mathrm{x}$ & & & $\mathrm{x}$ & $\mathrm{x}$ & & 1 \\
\hline $\begin{array}{l}\text { Natural and cultural heritage-intellectual and } \\
\text { scientific values }\end{array}$ & & $x$ & $\mathrm{x}$ & & $x$ & $x$ & & 1 \\
\hline
\end{tabular}

Legend: A-Assignment; DCM-Development concept of a municipality area, protection and development of its values; UPC-Urban planning concept; CPI-Concept of public infrastructure; CLL-Concept of landscape layout; CADUM-Determination of conditions for use of areas with different usage manner, determining the prevailing usage manner (major use); SPW—Specification of public works, public benefit measures; V-Value expression of the degree of content integration of ecosystem services in selected spatial planning documents according to Geneletti and Zardo [38] (modified).

\subsubsection{Plan Rationalization}

The content of plan rationalization explains the reasons for the implementation of the measures proposed in the text part. It is clear from the documents of all five cities that ecosystem services are not yet part of the interpretive methodology of plan rationalization. For example, the justification of the concept of landscape layout ÚPHK works with basic urban and landscape theories, presented on the specific spatial arrangement of the city of Hradec Králové.

The plan rationalization also includes the chapter, "Evaluation of meeting the requirements of the assignment". The example of plan rationalization of the spatial plan proposal of Hradec Králové (ÚPHK) presents the level of evaluation.

Requirement: "Respect public interests in the field of protection of biological diversity and environmental quality, especially in the form of consistent protection of specially protected areas, NATURA 2000 sites, wetlands, water protection zones, protected areas of natural water accumulation and mineral wealth, protection of agricultural, and forest land fund. Create territorial conditions for the implementation and respect of territorial systems of ecological stability (TSES) and the maintenance and improvement of ecological stability and for ensuring the ecological functions of the landscape and for the protection of landscape elements of a natural character in built-up areas. Create conditions for the protection of the landscape with regard to the target characteristics and types of landscape and create conditions for the use of natural resources" (Plan rationalization of spatial plan proposal of Hradec Králové).

Evaluation: "Done. The concept of ÚPHK consistently respects all principles of nature, landscape, and water protection, as well as natural elements in the territory, including all territories and areas that are the subject of protection. ÚPHK specifies supra-regional and regional elements of TSES, defines elements of local TSES, and creates conditions for its establishment. UPHK further defines the 
conditions for the protection of the landscape. Segments with natural character in a built-up area are defined as separate areas of greenery (areas of public spaces) ... ÚPHK respects and protects these areas as elements of fundamental compositional importance, which contribute to the diversity of the area and increase its ecological stability" (Plan rationalization of spatial plan proposal of Hradec Králové).

As is clear from the above cases, this assessment is rather formal and general, despite the fact that there is a space for the use of ecosystem services as indicators of the level of meeting the requirements of the assignment.

The individual ecosystem services, explicitly mentioned to justify the chosen solution, are listed in the subchapter, "Concept of landscape layout, delimitation of areas and determination of conditions for changes in their use, territorial system of ecological stability, permeability of the landscape, anti-erosion measures, protection against floods, recreation, mining, etc.". The significance of individual types of green areas is described, for example, as follows: "Areas of urban greenery must be preserved or implemented to fulfill all their functions. These green areas co-create a favorable environment for the population, help maintain and create a suitable microclimate (dampen temperature fluctuations, increase humidity, capture precipitation, reduce noise and dust, have a positive effect on air quality), clearly create a pleasant environment for daily short-term recreation (e.g., babysitting, sports activities, the possibility of sitting for senior citizens, a meeting place and space for community activities of the population), and last but not least, have a positive effect on the human psyche" (Plan rationalization of the Plzeň spatial plan).

\subsection{How Are Measures of Spatial Plans Targeted at Ecosystem Services?}

It is clear from the previous paragraphs that the measures of the spatial plans are mainly focused on natural components (urban, landscape greenery, water elements, occasionally soil and minerals) as sources of ecosystem services. This applies to the assignment, the text part, and the rationalization of the spatial plans. A simple and incomplete list of ecosystem services is used only to explain the importance of green areas. This is due to the overall methodological concept of creating land use plans. It must not be forgotten that spatial plans reflect not only the use of natural components, but also technical elements and systems. A spatial plan presents a uniform level of detail as a whole.

Figure 3 presents the recommendations, measures, and their groups, which, by their nature, fulfill the content of the concept of ecosystem services or support them directly or indirectly, and which have been identified in investigated spatial planning documents.

\subsection{What Are the Possibilities for Innovation of Spatial Plans through Ecosystem Services?}

The main tool in the creation of spatial plans, which will ensure the effective implementation of ecosystem services into spatial planning, is the assignment of a spatial plan. The existing legislative rules (Annex No. 6 to Decree No. 500/2006 Coll.) defining the structure of the Assignment allow this with their generality. However, this step cannot be approached in an uncoordinated manner; it is necessary to compare the detail of the ES's inclusion in the Assignment with other measures, such as the detail of the explanation of the technical infrastructure. Ways in which individual groups of main participants in the creation of the Spatial Plan Assignment can use ESA in the process of preparing the spatial plan are presented in Figure 4.

The text part of the spatial plan itself gives space for implementation, primarily in the approach. This means that if a society needs to define, for example, a new type of area or update one of the existing types of areas with the currently needed ecosystem service, it will also include it in the spatial plan. This also applies to the Assignment innovation. However, this mechanism is linked to the perception of societal values. Spatial planning is just a tool for their application.

Extending existing access to ecosystem services as an explanation of the measure is a logical step in plan rationalization. However, it is necessary to work with the entire ES group (e.g., according to TEEB), not just with a group of selected ones. 
It is also logical to use it in assessing the impact of the implementation of the spatial plan on sustainable development and the environment (SEA). Once again, however, it is necessary to accept that it is not possible to innovate in detail only the environmental pillar of sustainable development without considering a uniform level of detail for the economic and social pillar (due to their interconnectedness).
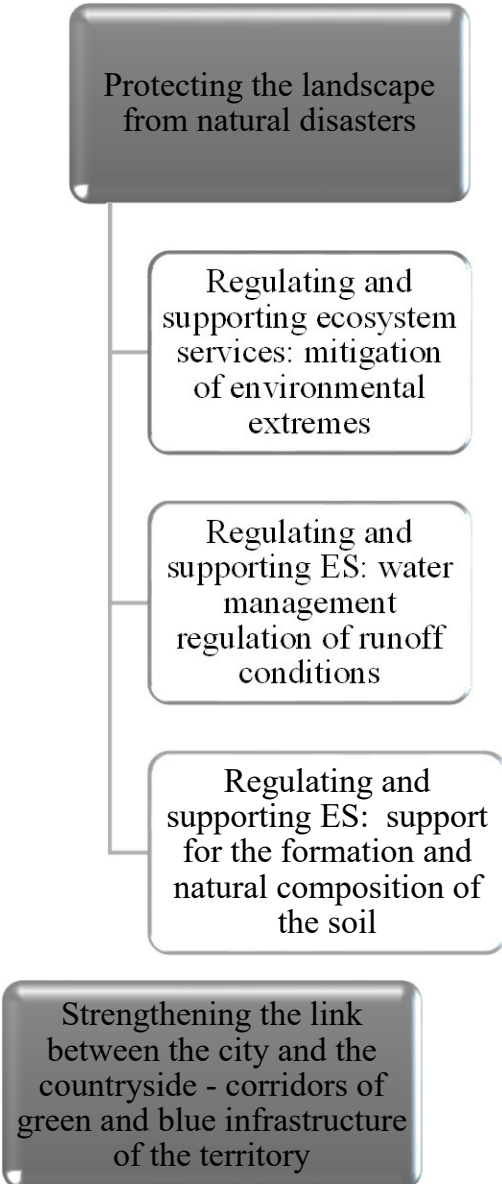

Provisioning ecosystem services: food resources, biomass resources

Regulating and supporting ES: support for species and ecosystem biodiversity, pollination

Cultural ecosystem services: landscape protection and aesthetics
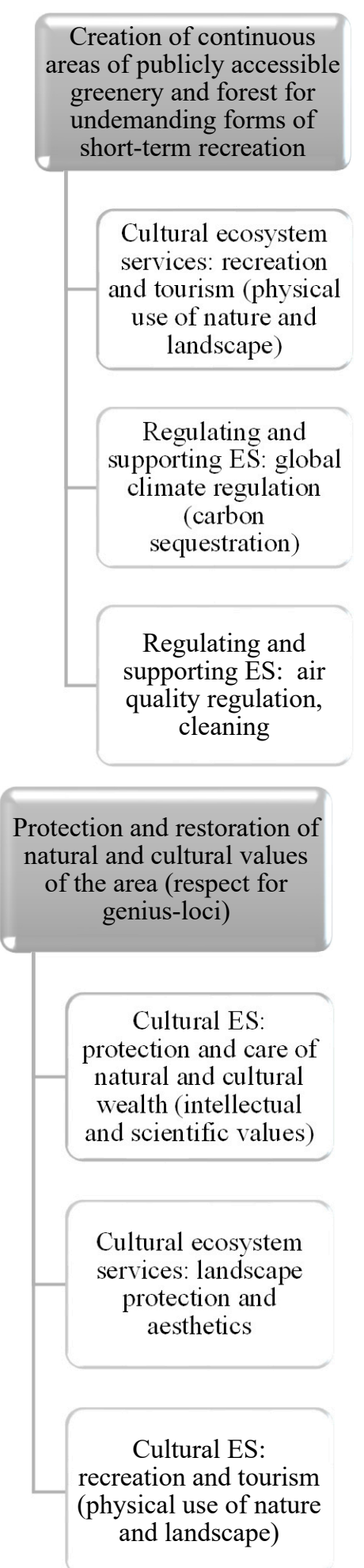
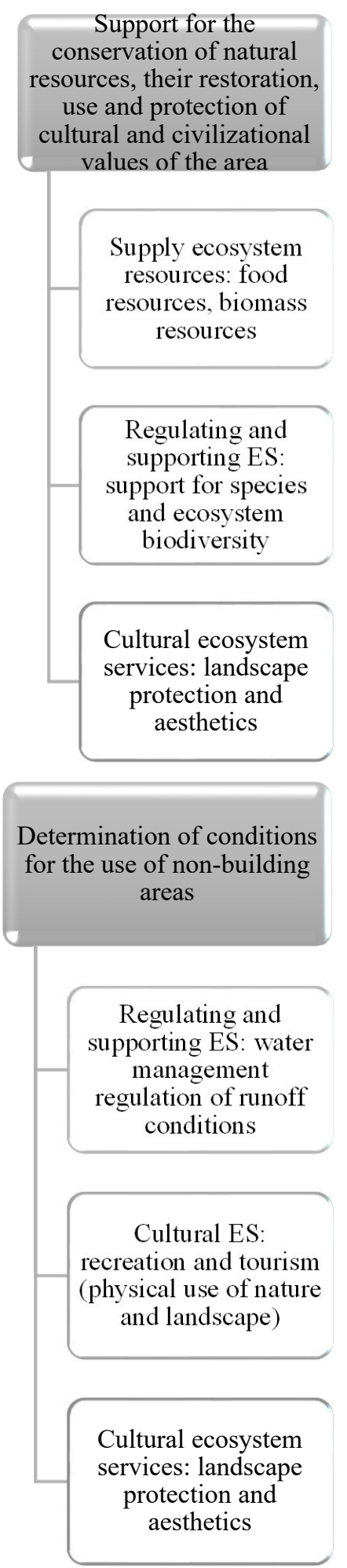

Figure 3. Identification of measures in spatial planning documents to support ecosystem services. 


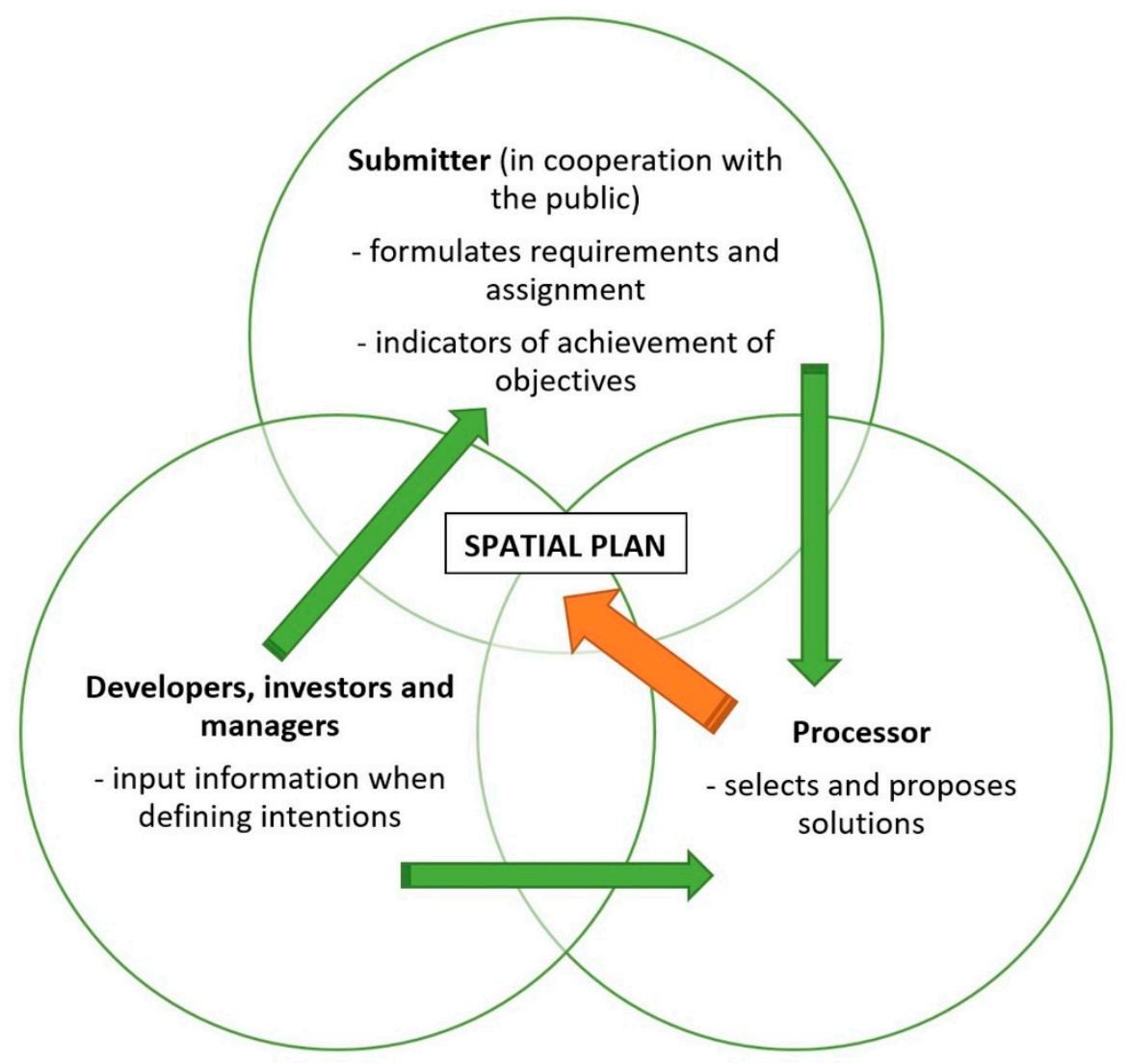

Figure 4. Ways in which individual groups of main participants in the creation of the Spatial Plan Assignment can use ESA in the process of preparing the spatial plan.

\section{Discussion}

It is essential that the ecological, socio-cultural, and economic values of the landscape be fully taken into account in planning and decision making [40,41]. Mapping and assessment of ecosystems and their services have a very high potential to support policy- and decision-making in a wide range of domains in policy, business, and society across the EU [42]. The essential tool of these processes is spatial planning.

A study of the current state of implementation of ecosystem services into spatial planning tools in the Czech Republic came to similar conclusions as analyses in other countries, cities, and regions.

Cortinovis and Geneletti [18] analyzed the implementation of ecosystem services in the spatial plans of twenty-two Italian cities. Spatial planning in Italy supports the production of settlement ecosystem services through a large number of measures. On the other hand, scientific knowledge has been only partially implemented in the planning process, and methodological support is still low $[18,35]$.

Valuation studies in urban areas for any given decision-support context are more demanding because of requirements for higher spatial resolution and multiple scales of analysis in sampling particular assets at specific locations within heterogeneous urban landscapes.

Although formally recognized in the ecosystem services literature, these values are rarely addressed at the operational level, and little has been said on how the ecosystem services approach may contribute to better incorporate non-economic values in urban planning [11].

A case study of the ten most populous municipalities in Ontario, Canada, determines whether and how ecosystem services have been incorporated in each of their land use plans. All categories of ecosystem services currently do exist in local and regional official plans, but the term ecosystem services is rarely used, missing an opportunity to clearly present the link between environmental protection and human well-being [10]. 
Kaczorowska et al. [43] investigated how the implementation of the urban ES concept in Stockholm is understood by different urban professionals, based on semi-structured interviews and a stakeholder workshop. Although recognizing the usefulness of the ES concept, the professionals identified many remaining challenges linked to integrating the concept into land use planning. These are analyzed in relation to the gap between ES science and ES policy and structured according to the different types of planning uncertainties they represent.

The process of integrating ES into urban planning and governance in Stockholm has already attracted considerable attention in policy and discussion about the values of ES. It has been suggested that ES might help to keep the region in the front of being sustainable by fostering an adaptive and transformative development that may maintain human well-being across complex and interlinked social, economic, and ecological systems [43,44].

In summary, all studies show that spatial planning documents are targeted at sustainable land use management. However, there is no methodological tool to innovate these documents with the concept of ecosystem services and social well-being.

Table 6 presents the results of selected studies focused on the use of ecosystem services in spatial planning documents.

Table 6. Investigated ecosystem services within spatial plans in selected studies.

\begin{tabular}{|c|c|c|c|c|c|c|}
\hline Evaluated Ecosystem Services & $\begin{array}{l}\text { Hansen et al., } \\
\quad 2015\end{array}$ & $\begin{array}{l}\text { Kabisch, } \\
2015\end{array}$ & $\begin{array}{l}\text { Cortinovis, } \\
\text { Geneletti, } \\
2018\end{array}$ & $\begin{array}{l}\text { Colavitti et al., } \\
2020\end{array}$ & $\begin{array}{l}\text { La Rosa } \\
2019\end{array}$ & Czechia \\
\hline Provisioning & $x$ & $x$ & & & & $\mathrm{x}$ \\
\hline food supply & $x$ & $x$ & $x$ & & & $x$ \\
\hline raw materials supply & $x$ & $x$ & & & & $x$ \\
\hline medicinal resources & $x$ & $x$ & & & & $x$ \\
\hline Regulating & $x$ & $x$ & & & & $x$ \\
\hline local climate regulation & $x$ & $x$ & $x$ & & & $x$ \\
\hline air quality regulation & $x$ & $x$ & $x$ & & & $x$ \\
\hline $\begin{array}{c}\text { carbon sequestration and } \\
\text { storage }\end{array}$ & $x$ & $x$ & & & & \\
\hline noise reduction & $x$ & $x$ & $x$ & & & $x$ \\
\hline run-off mitigation & $x$ & $x$ & $x$ & & & $x$ \\
\hline moderation of extreme events & $x$ & $x$ & $x$ & & & $x$ \\
\hline waste-water treatment & $x$ & $x$ & $x$ & & & $x$ \\
\hline $\begin{array}{l}\text { erosion prevention and } \\
\text { maintenance of soil fertility }\end{array}$ & $x$ & $x$ & & & & $x$ \\
\hline pollination & $x$ & $x$ & & & & \\
\hline biological control & $x$ & $x$ & & & & \\
\hline Supporting & $x$ & $x$ & & & & $x$ \\
\hline habitat for species & $x$ & $\mathrm{x}$ & & & & $\mathrm{x}$ \\
\hline $\begin{array}{c}\text { maintenance of genetic } \\
\text { diversity }\end{array}$ & $\mathrm{x}$ & $x$ & & & & \\
\hline Cultural & $x$ & $x$ & & & & $x$ \\
\hline $\begin{array}{l}\text { recreation and mental and } \\
\text { physical health }\end{array}$ & $x$ & $x$ & $x$ & & & $x$ \\
\hline tourism & $x$ & $x$ & & & & $x$ \\
\hline $\begin{array}{c}\text { aesthetic appreciation and } \\
\text { inspiration }\end{array}$ & $x$ & $x$ & & & & $x$ \\
\hline $\begin{array}{l}\text { spiritual experience and sense } \\
\text { of place }\end{array}$ & $x$ & $x$ & & & & \\
\hline education and learning & $x$ & $x$ & & & & \\
\hline In general & & & & $x$ & $x$ & $x$ \\
\hline $\begin{array}{l}\text { Recognition of term } \\
\text { "Ecosystem services" }\end{array}$ & $?$ & $\mathrm{x}$ & $?$ & $?$ & $\mathrm{x}$ & $\mathrm{N}$ \\
\hline Evaluated cities & $\begin{array}{c}\text { Berlin, Salzburg, } \\
\text { New York, } \\
\text { Stockholm, Seattle }\end{array}$ & Berlin & $\begin{array}{l}22 \text { cities in } \\
\text { Italy }\end{array}$ & $\begin{array}{l}\text { Milan, Bologna, } \\
\text { Florence, Rome }\end{array}$ & $\begin{array}{l}136 \text { Italian } \\
\text { urban plans }\end{array}$ & $\begin{array}{l}\text { Brno, Liberec, } \\
\text { Plzeň, Olomouc, } \\
\text { Hradec Králové }\end{array}$ \\
\hline
\end{tabular}

The analyzed spatial plans work with the statements that it is necessary to improve or support flood protection, biodiversity, ecological stability of forests, as well as recreational potential. The subchapters state that it is necessary to develop greenery or water features. The philosophy of the spatial plan and its assignment therefore supports both the provision of ecosystem services and the existence of their resources. Ecosystem services are therefore an important condition and element, even if the 
documents do not work directly with ESA. Perhaps this is why the main thing is missing here-a clear statement that, where possible, achieving the goal through ecosystem services and their resources will be preferred, rather than, for example, technical solutions (e.g., flood or noise control measures).

On the part of the contracting authority, it is therefore necessary to understand the concept of ecosystem services for the best possible formulation of the assignment and cooperation with the public (inclusion of social aspects—citizens' requirements). On the processor side, ecosystem services allow you to choose the two more environmentally friendly solutions.

From spatial planning proposals, it seems that it is sufficient for key urban development stakeholders to know that blue-green infrastructure provides ecosystem services, but they do not need to know what and how. The question remains whether this approach is sufficient. Is this sufficient knowledge for today's "smart cities" or "resilient cities" trends?

\section{Conclusions}

The analysis of the spatial plans of five regional centers in the Czech Republic-Brno, Plzeň, Liberec, Olomouc and Hradec Králové-showed gaps and potential for the implementation of ecosystem services in the spatial plans. The current approach to the creation of spatial plans in the Czech Republic is influenced by:

- unifying legislative rules

- stereotypical (traditional) approach to processing spatial plans

- low stakeholder awareness of international trends

- weak cooperation between research and practical institutions

- the need to maintain a coherent approach across sectors

- sectoral plans address ecosystem services in more detail than spatial plans

- participatory approach and public interest in sustainable urban development where 0 is neutral impact, + is positive impact, and - is negative impact.

From an environmental point of view, spatial plans in the Czech Republic are currently focused primarily on the resources of ecosystem services. They believe that by supporting the resource, they also support all its ecosystem services. On the one hand, this is true. On the other hand, it reduces the effectiveness of support, especially when one of the ecosystem services needs to be supported beyond the normal framework.

The analysis of the content of land use plans shows that most social attention is paid to flood control measures and recreation. At the general level, nature protection and ecological stability are mentioned, which indirectly declares a social interest in the protection of biodiversity. On the contrary, spatial planning in the Czech Republic ignores the support of life cycles and processes, pollination, or regulation of pests and diseases from the examined ES.

The spatial plan assignment appears to be an effective tool for the implementation of ecosystem services. The submitter, or through him the public, may, in the case of the knowledge of the ESA, set such conditions for land use and at the same time for the creation of a spatial plan that will support resources and the use of ecosystem services.

Raising public and decision makers awareness is the second important mechanism. It is this awareness that can influence the willingness to take an innovative approach to the assignment and thus to the elaboration of spatial plans., and as a final benefit, to improve the environment in cities and the countryside. In addition, it is a faster and more flexible way than "only" trying to change legislation. The current wording of the Building Act and related regulations gives sufficient scope for the implementation of ESA, as described above. For future studies, therefore, it is offered not only to analyze spatial planning documents, but also to compare the legislation of individual states, which gives space for the implementation of ecosystem services. 
Author Contributions: Conceptualization: J.S. and H.K.; methodology: H.K.; software: J.S.; validation: J.S. and H.K.; formal analysis: J.S. and H.K.; investigation: H.K.; resources: J.S. and H.K.; data curation: H.K.; writing-original draft preparation: J.S. and H.K.; writing—review and editing: J.S. and H.K.; visualization: J.S.; supervision: J.S.; project administration: J.S. and H.K.; funding acquisition: J.S. All authors have read and agreed to the published version of the manuscript.

Funding: This research received no external funding.

Acknowledgments: The article was created in relation to the project EHP-CZ02-OV-1-032-2015: Raising awareness and publicity of the importance of forest functions in the landscape and near-natural watercourses in urban areas as a part of basin ecosystem services. The authors would like to thank Jitka Fialová for consultations.

Conflicts of Interest: The authors declare no conflict of interest.

\section{References and Note}

1. Piwowarczyk, J.; Kronenberg, J.; Dereniowska, M.A. Marine ecosystem services in urban areas: Do the strategic documents of Polish coastal municipalities reflect their importance? Landsc. Urban Plan. 2013, 109, 85-93. [CrossRef]

2. Woodruff, S.C.; BenDor, T.K. Ecosystem services in urban planning: Comparative paradigms and guidelines for high quality plans. Landsc. Urban Plan. 2016, 152, 90-100. [CrossRef]

3. Biggs, R.; Schlüter, M.; Schoon, M.L. Principles for Building Resilience: Sustaining Ecosystem Services in Social-Ecological Systems; Cambridge University Press: Cambrigde, UK, 2015.

4. Grêt-Regamey, A.; Celio, E.; Klein, T.M.; Hayek, U.W. Understanding ecosystem services trade-offs with interactive procedural modeling for sustainable urban planning. Landsc. Urban Plan. 2013, 109, 107-116. [CrossRef]

5. Brauman, K.A.; Daily, G.C.; Duarte, T.K.; Mooney, H.A. The nature and value of ecosystem services: An overview highlighting hydrologic services. Ann. Rev. Environ. Resour. 2007, 32, 67-98. [CrossRef]

6. Baró, F.; Palomo, I.; Zulian, G.; Vizcaino, P.; Haase, D.; Gómez-Baggethun, E. Mapping ecosystem service capacity, flow and demand for landscape and urban planning: A case study in the Barcelona metropolitan region. Land Use Policy 2016, 57, 405-417. [CrossRef]

7. Albert, C.; Galler, C.; Hermes, J.; Neuendorf, F.; von Haaren, C.; Lovett, A. Applying ecosystem services indicators in landscape planning and management: The ES in planning framework. Ecol. Indic. 2016, 61, 100-113. [CrossRef]

8. Burkhard, B.; Kroll, F.; Nedkov, S.; Müller, F. Mapping ecosystem service supply, demand and budgets. Ecol. Indic. 2012, 21, 17-29. [CrossRef]

9. Barbosa, O.; Tratalos, J.A.; Armsworth, P.R.; Davies, R.G.; Fuller, R.A.; Johnson, P.; Gaston, K.J. Who benefits from access to green space? A case study from Sheffield, UK. Landsc. Urban Plan. 2007, 83, 187-195. [CrossRef]

10. Lam, S.H.; Conway, M. Ecosystem services in urban land use planning policies: A case study of Ontario municipalities. Land Use Policy 2018, 77, 641-651. [CrossRef]

11. Gómez-Baggethun, E.; Barton, D.N. Classifying and valuing ecosystem services for urban planning. Ecol. Econ. 2013, 86, 235-245. [CrossRef]

12. Andersson, E.; Tengö, M.; McPhearson, T.; Kremer, P. Cultural ecosystem services as a gateway for improving urban sustainability. Ecosyst. Serv. 2014, 12, 165-168. [CrossRef]

13. BenDor, T.K.; Spurlock, D.; Woodruff, S.C.; Olander, L. A research agenda for ecosystem services in American environmental and land use planning. Cities 2017, 60, 260-271. [CrossRef]

14. Holzinger, O.; Laughlin, P.; Grayson, N. Planning for Sustainable Land-Use: The Natural Capital Planning Tool Project; RICS Research: London, UK, 2015.

15. Jansson, Å. Reaching for a sustainable, resilient urban future using the lens of ecosystem services. Ecol. Econ. 2013, 86, 285-291. [CrossRef]

16. Rall, E.; Bieling, C.; Zytynska, S.; Haase, D. Exploring city-wide patterns of cultural ecosystem service perceptions and use. Ecol. Indic. 2017, 77, 80-95. [CrossRef]

17. Kabisch, N.; Qureshi, S.; Haase, D. Human-environment interactions in urban green spaces: A systematic review of contemporary issues and prospects for future research. Environ. Impact Assess. Rev. 2015, 50, $25-34$. [CrossRef]

18. Cortinovis, C.; Geneletti, D. Ecosystem services in urban plans: What is there, and what is still needed for better decisions. Land Use Policy 2018, 70, 298-312. [CrossRef] 
19. Niedźwiecka-Filipiak, I.; Rubaszek, J.; Potyrała, J.; Filipiak, P. The method of planning green infrastructure system with the use of landscape-functional units (method LaFU) and its implementation in the Wrocław Functional Area (Poland). Sustainability 2019, 11, 394. [CrossRef]

20. Mascarenhas, A.; Ramos, T.B.; Haase, D.; Santos, R. Ecosystem services in spatial planning and strategic environmental assessment-A European and Portuguese profile. Land Use Policy 2015, 48, 158-169. [CrossRef]

21. Wilkinson, C.; Saarne, T.; Peterson, G.D.; Colding, J. Strategic spatial planning and the ecosystem services concept-An historical exploration. Ecol. Soc. 2013, 18. [CrossRef]

22. Grădinaru, S.R.; Iojă, C.I.; Pătru-Stupariu, I.; Hersperger, A.M. Are spatial planning objectives reflected in the evolution of urban landscape patterns? A framework for the evaluation of spatial planning outcomes. Sustainability 2017, 9, 1279. [CrossRef]

23. Depietri, Y.; Dahal, K.; McPhearson, T. Multi-hazard risks in New York City. Nat. Hazards Earth Syst. Sci. 2018, 18, 3363-3381. [CrossRef]

24. Colucci, A. Towards resilient cities. Comparing approaches/strategies. Tema. J. Land Use Mobil. Environ. 2012, 5, 101-116.

25. Braat, L.C.; De Groot, R. The ecosystem services agenda: Bridging the worlds of natural science and economics, conservation and development, and public and private policy. Ecosyst. Serv. 2012, 1, 4-15. [CrossRef]

26. Schröter, M.; Kraemer, R.; Mantel, M.; Kabisch, N.; Hecker, S.; Richter, A.; Neumeier, V.; Bonn, A. Citizen science for assessing ecosystem services: Status, challenges and opportunities. Ecosyst. Serv. 2017, 28, 80-94. [CrossRef]

27. Pechanec, V.; Machar, I.; Sterbova, L.; Prokopova, M.; Kilianova, H.; Chobot, K.; Cudlin, P. Monetary valuation of natural forest habitats in protected areas. Forests 2017, 8, 427. [CrossRef]

28. Albert, C.; Hauck, J.; Buhr, N.; Von Haaren, C. What ecosystem services information do users want? Investigating interests and requirements among landscape and regional planners in Germany. Landsc. Ecol. 2014, 29, 1301-1313. [CrossRef]

29. Hansen, R.; Frantzeskaki, N.; McPhearson, T.; Rall, E.L.; Kabisch, N.; Kaczorowska, A.; Kain, J.-H.; Artmann, M.; Pauleit, S. The uptake of the ecosystem services concept in planning discourses of European and American cities. Ecosyst. Serv. 2015, 12, 228-246. [CrossRef]

30. OpenNESS. Operationalisation of Natural Capital and Ecosystem Services. 2012. Available online: http: //www.openness-project.eu/about (accessed on 23 June 2020).

31. Burkhard, B.; Maes, J.; Santos-Martin, F.; Geneletti, D.; Stoev, P.; Müller, F.; Kopperoinen, L.; Liekens, I.; Vihervaara, P.; Nedkov, S.; et al. Enhancing ecoSysteM sERvices mApping for poLicy and Decision mAking (ESMERALDA). Horizon 2020-EU.3.5.2-Protection of the Environment, Sustainable Management of Natural Resources, Water, Biodiversity and Ecosystems. 2018. Available online: https://www.researchgate.net/ project/ESMERALDA-Enhancing-ecosystem-services-mapping-for-policy-and-decision-making (accessed on 23 June 2020).

32. Santos-Martín, F.; Geneletti, D.; Burkhard, B. Mapping and assessing ecosystem services: Methods and practical applications. One Ecosyst. 2019, 4, e35904. [CrossRef]

33. Act No. 183/2006 Coll. On Spatial Planning and Building Regulations.

34. Kabisch, N. Ecosystem service implementation and governance challenges in urban green space planning-The case of Berlin, Germany. Land Use Policy 2015, 42, 557-567. [CrossRef]

35. Colavitti, A.M.; Floris, A.; Serra, S. Urban Standards and Ecosystem Services: The Evolution of the Services Planning in Italy from Theory to Practice. Sustainability 2020, 12, 2434. [CrossRef]

36. La Rosa, D. Why is the inclusion of the ecosystem services concept in urban planning so limited? A knowledge implementation and impact analysis of the Italian urban plans. Socio-Ecological Pr. Res. 2019, 1, 83-91. [CrossRef]

37. Geneletti, D.; Cortinovis, C.; Zardo, L.; Esmail, B.A. Planning for Ecosystem Services in Cities; Briefs in Environmental Sciences; Springer: Berlin/Heidelberg, Germany, 2020. [CrossRef]

38. Geneletti, D.; Zardo, L. Ecosystem-based adaptation in cities: An analysis of European urban climate adaptation plans. Land Use Policy 2016, 50, 38-47. [CrossRef]

39. Mederly, P.; Černecký, J. (Eds.) A Catalogue of Ecosystem Services in Slovakia. Benefits to Society; Springer International Publishing: Berlin/Heidelberg, Germany, 2020; p. 235. ISBN 978-3-030-46507-0. 
40. De Groot, R. Function-analysis and valuation as a tool to assess land use conflicts in planning for sustainable, multi-functional landscapes. Landsc. Urban Plan. 2006, 75, 175-186. [CrossRef]

41. Panagopoulos, T.; Duque, J.A.G.; Dan, M.B. Urban planning with respect to environmental quality and human well-being. Environ. Pollut. 2016, 208, 137-144. [CrossRef] [PubMed]

42. Geneletti, D.; Adem Esmail, B.; Cortinovis, C.; Arany, I.; Balzan, M.; van Beukering, P.; Bicking, S.; Borges, P.; Borisova, B.; Broekx, S.; et al. Ecosystem services mapping and assessment for policy- and decision-making: Lessonslearned from a comparative analysis of European case studies. One Ecosyst. 2020, 5, e53111. [CrossRef]

43. Kaczorowska, A.; Kain, J.H.; Kronenberg, J.; Haase, D. Ecosystem services in urban land use planning: Integration challenges in complex urban settings-Case of Stockholm. Ecosyst. Serv. 2016, 22, $204-212$. [CrossRef]

44. Elmqvist, T.; Fragkias, M.; Goodness, J.; Güneralp, B.; Marcotullio, P.J.; McDonald, R.I.; Parnell, S.; Schewenius, M.; Sendstad, M.; Seto, K.C.; et al. (Eds.) Urbanization, Biodiversity and Ecosystem Services: Challenges and Opportunities; Springer: Berlin/Heidelberg, Germany, 2013.

Publisher's Note: MDPI stays neutral with regard to jurisdictional claims in published maps and institutional affiliations.

(C) 2020 by the authors. Licensee MDPI, Basel, Switzerland. This article is an open access article distributed under the terms and conditions of the Creative Commons Attribution (CC BY) license (http://creativecommons.org/licenses/by/4.0/). 